Article

\title{
Landslide Hazard Knowledge, Risk Perception and Preparedness in Southeast Bangladesh
}

\author{
Edris Alam $\mathbb{D}$
}

Faculty of Resilience, Rabdan Academy, Abu Dhabi 114646, UAE; ealam@ra.ac.ae; Tel.: +971-2-5999111

Received: 28 June 2020; Accepted: 3 August 2020; Published: 5 August 2020

check for updates

\begin{abstract}
Over the last thirty years, Bangladesh has been experiencing hill cutting problems and subsequent landslide occurrence in its southeastern hilly region. Since 2000, landslides have caused over 500 deaths, mostly in informal settlements in southeast Bangladesh. The most significant single event was the 2007 landslide causing 127 deaths in Chittagong's informal settlements. The landslide events took over 110 people in Rangamati on 12 June 2017. In the scenario of rising deaths by landslides in the southeastern region, this research aimed to understand communities' landslide hazard knowledge, reasons for living in at-risk areas, risk perception and preparedness. This research applied both quantitative (i.e., structural questionnaire) and qualitative (i.e., semi-structured and open-ended questionnaire and informal interviews) data collection techniques to assess hill-top and hill-side dwellers knowledge, risk perception and preparedness to landslides in southeast Bangladesh. The investigation conducted face-to-face interviews with 208 community members, 15 key informant interviews, three Focus Group Discussions (FGDs) and field observations and visits in southeast Bangladesh. The findings suggest that unplanned development activities, overpopulation, settlement along hill slopes and ineffective disaster risk reduction efforts are the anthropogenic contributories accompanying climate-change induced increased torrential rainfall are the main reasons for the increase of landslide occurrence. The results suggest that community members perceive a low-risk for landslides, despite the community's location in high-risk areas. The community's perception of low risk results in a lack of preparedness and an unwillingness to relocate a comparatively safer place. It was noted that landslide disaster preparation depends on the communities' development maturity, house ownership, ethnicity, gender and economic status of the residents. It is suggested that the place of relocation for residents living in the high-risk areas should be selected with full consideration of psychosocial aspects of the community, particularly providing acceptable livelihood options.
\end{abstract}

Keywords: landslide; hazard; risk; perception; preparedness

\section{Introduction}

Bangladesh is susceptible to a variety of natural and human-induced hazards including tropical cyclones, earthquakes, tsunamis, floods, droughts and landslides due to its geographical location and fragile landscape. The eastern part of Bengal Basin is bordered by the Tripura Hills to the north and the Chittagong Hills to the south. These hills are composed of folded sediments during the Pleistocene through the Pliocene with a height up to $609.6 \mathrm{~m}$ above mean sea level (MSL) [1]. Landslides become recurrent phenomena in the region in recent decades. The Government of Bangladesh (GoB) has been successful in reducing resultant deaths from tropical cyclones. However, in recent years, landslides have been a major risk in the southeast region of Bangladesh. Landslides caused over 500 deaths in southeast Bangladesh with the majority in informal settlements in Chittagong City since 2000. Both natural and anthropogenic causes are responsible for landslides in the country. The causes include excessive and prolonged rainfall in a short period; unmanaged slope cutting loose soil structures and deforestation in the hilly areas; and seismic activity [2-4]. Hill-cutting areas have been used for 
formal and informal settlement development, and the increase of these settlements (Figure 1) along the foothills has been contributing to landslide events.

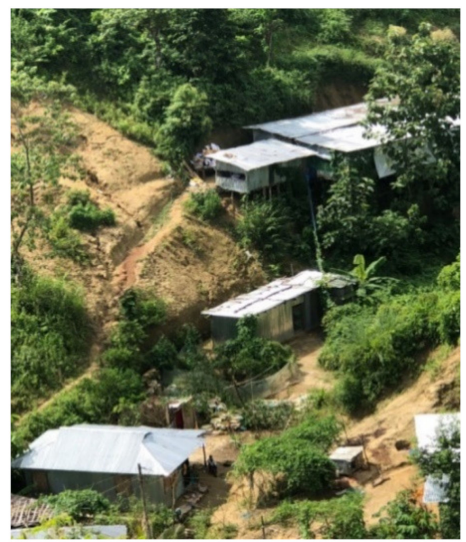

(a)

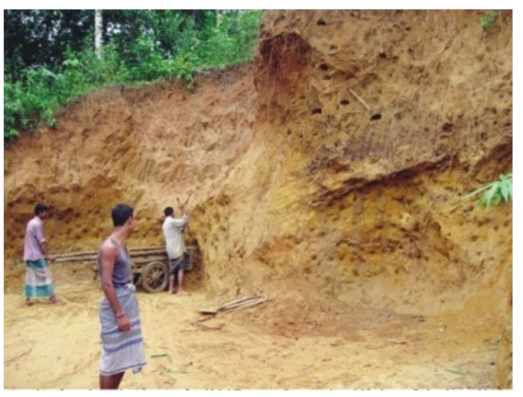

(c)

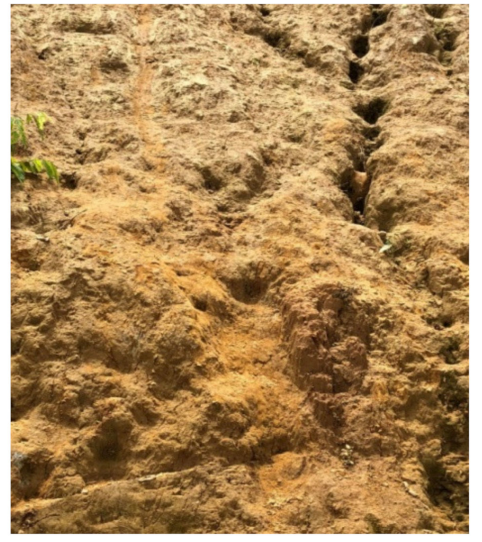

(b)

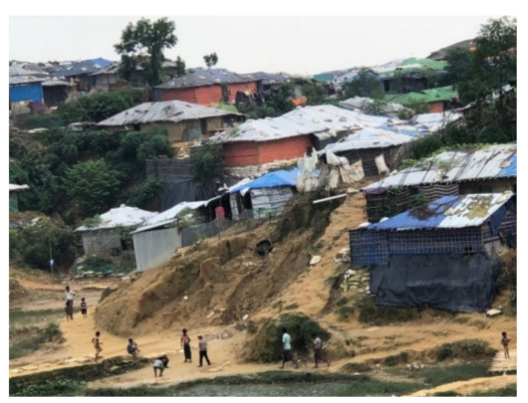

(d)

Figure 1. (a) Houses along highly susceptible hills in Rangamati; (b) loose soil structure in Rangamati; (c) Continuous illegal hill cutting in Chittagong; and (d) houses in Rohingya refugee camp in Cox's Bazar, Bangladesh.

Following the independence of Bangladesh in 1971, the commercial activities of Chittagong City increased remarkably. The population of the city rose to 2,023,000 in 1990 from 289,000 in 1950. Due to an increase in the human population and commercial activities, there was an expansion of new land development in Rangamati City. From the early 1980s, there has been a trend of hill cutting to accommodate the excessive land demand. Since the late 1990s, the problem of hill cutting has attracted print and electronic media coverage due to the decrease of wetlands in and around Chittagong City. The hill-cutting has increased water-logging and landslide occurrence [5]. The 2007 landslide events caused 127 deaths in informal settlements in Chittagong. On 12 June 2017, landslides occurred in southeast Bangladesh and ended over 150 lives [6-8]. An estimation of landslide occurrence from print media sources by the author for another endeavour suggests that over 150 landslides significantly affected different areas in southeast Bangladesh. Bangladesh may experience more landslides and sub-sequential deaths because of the ongoing increases in housing development in hill cut areas. To reduce deaths associated with landslides, the GoB is undertaking short-term preparedness and response measures, which may have little impact on risk reduction.

The GoB claims that sufficient landslide risk reduction strategies have been undertaken. However, the deaths associated with landslides are increasing with every disaster occurrence. There is a conspicuous gap in the domain of understanding and integration of the science of landslide occurrence, community knowledge and risk perception, disaster preparedness and response. As such, reducing the gap in knowledge requires addressing several specific scientific and technical issues related to the diverse disciplinary fields of hazard and risk assessment and emergency response. Risk reduction 
strategies require involving the vulnerable community in the landslide hazard assessment and implementing the appropriate risk management strategies. To minimise deaths and injuries associated with landslide hazards, it is necessary to find practical solutions on how community vulnerability to landslide hazards could be mitigated and implemented.

Based on rationale above, two research objectives were identified: (1) to assess the communities' perception of the causes of the recent increases in landslide hazards and associated problems in southeast Bangladesh; and (2) to assess the hill-top and hill-side dwellers' hazard knowledge, risk perception and preparedness to evacuate during landslides in southeast Bangladesh. To achieve the objective, this research applied both quantitative (i.e., structural questionnaire) and qualitative (i.e., semi-structured and open-ended questionnaire and informal interviews) data collection techniques to consult residential communities in southeastern Bangladesh.

In the following sections, the literature on landslide risk reduction strategies in Bangladesh is discussed and the research gap is identified. Subsequently, the research objectives and methods are provided, followed by the results of the research. Finally, the conclusions and implications of the research are stipulated.

\section{Literature Review and Theoretical Framework}

A plethora of research from various local, regional and international Institutions documented hill cutting problems and subsequent landslide occurrence in Chittagong City [9-12]. Islam et al. [11] suggested that slope failure hazards are occurring every year due to heavy rainfall in loose soil structure in the hill cutting areas in southeast Bangladesh. Previous research analysed historical accounts of landslide disasters, physical and social accounts of landslide risk and mitigation approaches in Bangladesh (Table 1).

Table 1. Previous studies on landslides in Bangladesh.

\begin{tabular}{|c|c|}
\hline Focus of Discussion & References \\
\hline \multicolumn{2}{|l|}{ Physical Dimensions of Landslide Risk } \\
\hline Landslide susceptibility mapping in Chittagong City Corporation & [13-17] \\
\hline Slope stability of hilly areas in Chittagong City Corporation & [18] \\
\hline Rainfall triggered landslide generation & {$[19,20]$} \\
\hline \multicolumn{2}{|l|}{ Social Dimensions of Landslide Risk } \\
\hline Increases in unprotected foothill settlement & {$[21]$} \\
\hline Anthropogenic hill cutting induced landslides & {$[3,12]$} \\
\hline Lack of knowledge about landslide risk areas & [22] \\
\hline Lack of institutional arrangement for landslide risk reduction & [23] \\
\hline Effects and vulnerability assessment & {$[24]$} \\
\hline Short term changes in the institutional arrangement for risk reduction & [2] \\
\hline A political ecology of landslide occurrence & {$[4,25]$} \\
\hline \multicolumn{2}{|l|}{ Risk Reduction Approaches } \\
\hline Landslide risk mitigation through modern and indigenous knowledge & {$[26,27]$} \\
\hline \multicolumn{2}{|l|}{ Landslide Inventory } \\
\hline Landslide Inventory Chittagong Metropolitan Area & [9] \\
\hline
\end{tabular}

To mitigate the impacts of landslides, it is essential to understand the factors that influence people's ability to respond to future events effectively. A review of the literature indicates that the following four issues are crucial to this study.

1. Hazard assessment 
2. Hazard knowledge

3. Risk perception

4. Disaster preparedness

To mitigate the effects of natural hazards, it is essential to understand how people living in at risk locations perceive hazards and risk and to appreciate their knowledge and preparedness concerning particular hazards [28]. Hazards may be defined as a process, phenomenon or human activity that may cause loss of life, injury or other health impacts, property damage, social and economic disruption or environmental degradation. Enhancement of hazard knowledge may result in an increase in risk perception and preparedness actions to reduce future vulnerability [29]. Hazard knowledge and risk perception are essential components of risk mitigation approaches [30]. The reason is an individual is unlikely to be prompted to take part in mitigation measures for natural hazards without any appreciation of the hazard and risk [31].

Preparedness is:

"the knowledge and capacities developed by governments, professional response and recovery organisations, communities and individuals to effectively anticipate, respond to, and recover from the impacts of likely, imminent or current hazard events or conditions [32]."

Disaster risk may be defined as the potential loss of life, injury or destroyed or damaged assets which could occur to a system, society or a community in a specific period, determined probabilistically as a function of hazard, exposure, vulnerability and capacity [32]. Disaster risk not only depends on frequency, intensity and duration of hazards but also varies with characteristics of community, economies and politics [33-35]. To implement effective risk reduction strategies, a complete understanding of physical, social, economic, cultural, environmental and institutional dimensions of vulnerability to landslides must be carefully assessed [36,37]. However, in the past, limited research was conducted to assess vulnerability to landslides in southeast Bangladesh. As such, this research aimed to fill this gap by exploring landslide hazard knowledge, risk perception and preparedness in southeast Bangladesh.

\section{Research Methods and Materials}

This research addressed and resolved several specific scientific and technical issues related to the diverse disciplinary fields of: (1) hazard identification and assessment; and (2) disaster preparation. To understand hill-top and hill-side dwellers hazard knowledge, risk perception and preparedness towards evacuation during landslides in southeast Bangladesh, this research applied both quantitative (i.e., structured questionnaires) and qualitative (i.e., semi-structured questionnaires, open-ended questionnaires, focus group discussions (FGDs) and informal interviews) field survey techniques. Both approaches have their limitations. However, mixed methods may gain more robust evidence than either qualitative or quantitative approaches provide alone. In total, 208 residents selected by purposive sampling technique from southeast Bangladesh were interviewed on hazard knowledge, risk perception, disaster preparedness, emergency responses and evacuation. Before the conducting sample survey, a list of high-risk landslide areas was identified from documentary sources and consultation with district administrators and residents in Rangamati, Chittagong and Cox's Bazar (Figure 2). In total, 15 key informant interviews were conducted with experts and civil administrators in Rangamati, Chittagong and Cox's Bazar. Three FGDs were conducted among communities in Rangamati, Chittagong and Cox's Bazar consisting of eight members in each meeting. The duration of each FGD was $1 \mathrm{~h}$. The time and venue of the meeting was determined in consultation with the participants. The questionnaire gathered general knowledge about landslide hazards, past experiences of landslides, the reasons for living in high-risk areas, preparation and evacuation procedure and how proactive disaster preparation can be developed and implemented. This questionnaire was pre-tested in the field to determine its adequacy, ascertain applicability and address any deficiencies. Throughout the research, norms of social survey and participants' rights were maintained. 


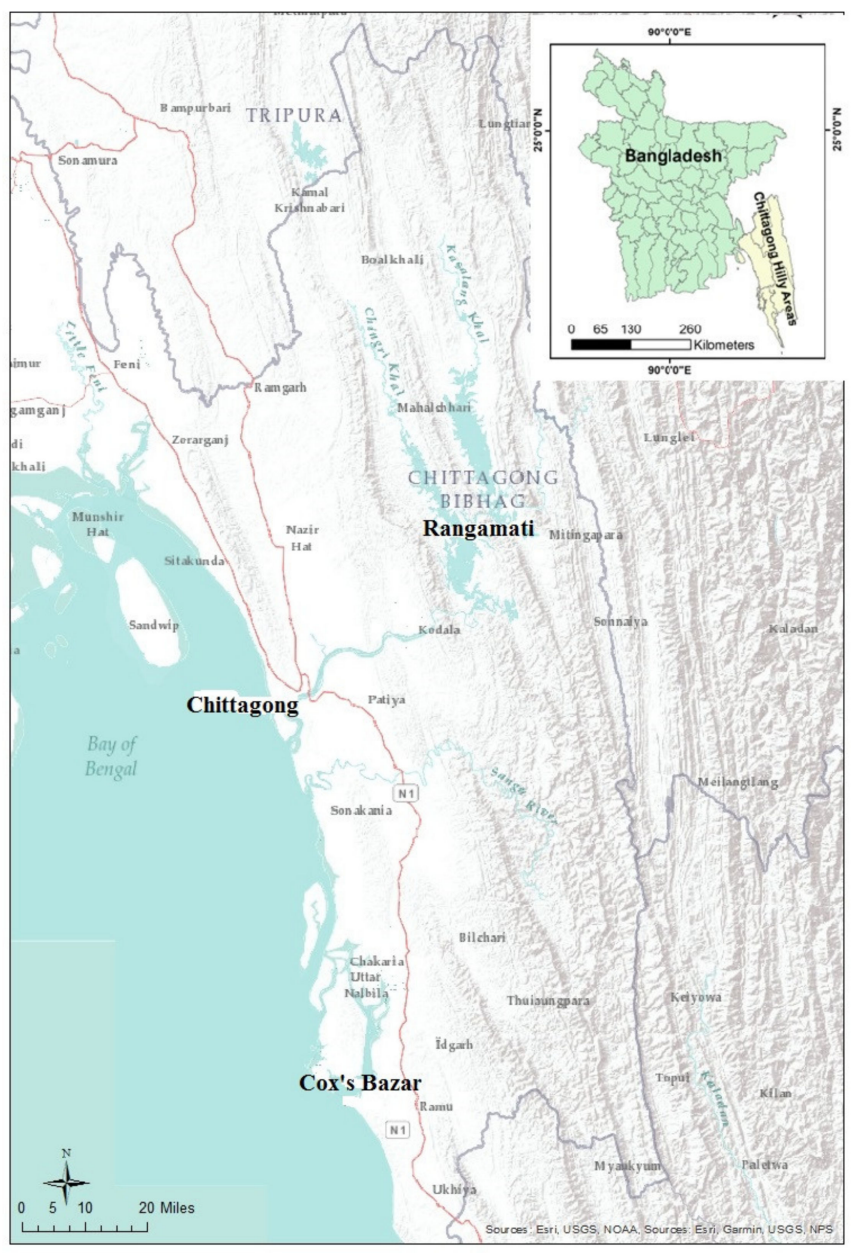

Figure 2. The location of southeast Bangladesh. Field study districts include Rangamati, Chittagong and Cox's Bazar.

\section{Results and Discussion}

In the following sections, key findings are provided that should be of interest to organisations responsible for developing landslide risk mitigation strategies and for assisting the GOB in determining the appropriateness of the government's preparedness strategy. Sequentially, this paper explores: socio-demographic characteristics of the respondents; communities' perception of the causes of increasing landslide hazards; migration and landslide susceptibility; the reasons for living in high-risk areas; the challenges of relocation to safe areas; and conclusions and implications.

\subsection{Socio-Demographic Characteristics of the Respondents}

The 208 respondents consisted of $60 \%$ males and $40 \%$ females. The respondents' age ranges were categorised as 20-30, 31-40, 41-60, 61-70 and >70 years, and the percentage for each group were $35 \%$, $34 \%, 13 \%, 8 \%, 6 \%$ and $4 \%$, respectively. The average family size of the respondents was six members. The percentage breakdown of the completion of schooling up to junior level, secondary school certificate (SSC), higher secondary school certificate (HSC), graduate and postgraduate levels were $45 \%, 6 \%, 8 \%$, $7 \%$ and $1 \%$, respectively. The remaining $33 \%$ of the respondents were illiterate. Of the respondents, $14 \%$ were unemployed and the professions of the remaining $86 \%$ included housewives, businesspeople, students, day labours, transport workers, teachers, farmers and government employees, at $35 \%$, $14 \%, 11 \%, 10 \%, 8 \%, 6 \%, 3 \%$ and $1 \%$ respectively. The house structure of the respondents were semi-built, bamboo-made, built, corrugated iron sheet and polythene sheet at 53\%, 26\%, $12 \%, 6 \%$ and $3 \%$ respectively. The ownerships of houses that included personally owned, rental, inherited 
from parents, government camp and lease were $67 \%, 21 \%, 5 \%, 4 \%$ and $3 \%$, respectively. On average, the duration of occupying is 12 years. The duration of occupying a residence for $0-5,6-10,11-15,16-20$ and over 20 years account for $23 \%, 27 \%, 9 \%, 7 \%$ and $34 \%$ respectively. The respondents' house locations included hill slope, valley area and hill-top and were occupied at $45 \%, 36 \%$ and $19 \%$, respectively. The average monthly income of the respondents was USD 60 . Of the respondents, $25 \%$ suggested there was no cash income. Of the remaining $75 \%$ of respondents, those with income range of below Taka (1 USD equaled to 85 Bangladeshi Taka (currency unit in Bangladesh) in June 2020) 5000, 5001-10,000, $10,001-20,000$ and above 20,000 were $12 \%, 30 \%, 26 \%$ and $7 \%$, respectively.

\subsection{Communities' Perception of the Causes of Increasing in Landslide Hazards}

In response to the increase in recent landslide occurrence, $59 \%$ of residents attributed this to both natural and man-made causes. Separately, they opined that natural and man-made reasons constituted $39 \%$ and $2 \%$, respectively. Of the natural causes, the residents believe that heavy rainfall is the most determining factor for landslide occurrence (Table 2). This view coincides with expert opinion, which identified there was a record rainfall of $397 \mathrm{~cm}$ in Rangamati and $190 \mathrm{~cm}$ in Chittagong immediately before the 13 June 2017 landslide [38]. Similarly, on 12 June 2007, a rainfall of $397 \mathrm{~cm}$ triggered landslides causing 150 deaths in Chittagong. Heavy rainfall invades inside through soil and infiltrates underneath the surface, creating pressure on the subsoil, and, subsequently, hilly soils become soft and loose and slides down to the surface [23,39]. Following the 2017 landslide, the residents who live close to landslide-prone areas become anxious if heavy rainfall starts in the area. From the experience of recent landslides, the residents believed that the occurrence of heavy rainfall for an extended period generates landslides (Table 3). Generally, the residents in Rangamati do not want to attribute causes of landslide occurrence to man-made activities. However, when directed to some specific man-made reasons for landslide occurrence, they opined that recent increases in hill cutting, deforestation and human settlement in risk areas are contributory factors to the landslides (Table 4). The local communities believed that, on the night of 12 June 2017, exceptionally severe thunderstorms occurred which shivered hilly areas. Heavy rainfall coupled with thunderstorms caused fragmentation and movement of soils in the hilly areas, which subsequently caused landslides.

Table 2. Natural causes of landslide occurrence.

\begin{tabular}{ccc}
\hline Natural Factors & Frequency & Percentage \\
\hline Heavy rainfall & 192 & 52.75 \\
\hline Unstable soil & 58 & 15.93 \\
\hline Thunderstorm & 40 & 10.99 \\
\hline Steep slope topography & 38 & 10.44 \\
\hline Earthquakes & 36 & 9.89 \\
\hline Total & 364 & 100
\end{tabular}

Source: Field survey, August 2018 (Note: Multiple responses were counted).

Table 3. Characteristic of rainfall which triggers landslide occurrence.

\begin{tabular}{ccc}
\hline Characteristics of Rainfall & Frequency & Percentage \\
\hline Heavy rainfall in a long period & 104 & 50.0 \\
\hline Heavy rainfall in a short period & 76 & 36.5 \\
\hline Low-intensity rainfall in long period & 18 & 8.7 \\
\hline Low-intensity rainfall in a short period & 10 & 4.8 \\
\hline Total & 208 & 100.0 \\
\hline Source: Field survey, August 2018.
\end{tabular}


Table 4. Anthropogenic causes of landslide occurrence.

\begin{tabular}{ccc}
\hline Anthropogenic Causes & Frequency & Percentage \\
\hline Deforestation & 64 & 34.04 \\
\hline Hill cutting & 68 & 36.17 \\
\hline Increases of the settlement in slope area due to migration & 24 & 12.77 \\
\hline Natural increases in population & 12 & 6.38 \\
\hline Road construction & 8 & 4.25 \\
\hline Increases of the settlement in adjacent areas & 8 & 4.26 \\
\hline Changes in the natural drainage & 4 & 2.13 \\
\hline Total & 188 & 100 \\
\hline
\end{tabular}

Source: Field survey, August 2018 (Note: multiple responses were counted).

\subsection{Migration and Landslide Susceptibility}

The people who migrate to a new place experience more losses and casualties by disasters than that of the native population because the former lack the knowledge about hazards and have limited social networks and previous experience dealing with disasters [40]. Of the 208 participants, 53\% migrated from other areas in the last decades. Additionally, 59\% of respondents moved their locations at least two times due to both displacements by natural hazards and seeking a better life and livelihood opportunities in more secure places. The reasons for migration include looking for a new place to live, availability of job opportunities, education for children and business purposes (Table 5). Informal discussions with residents suggest that some dwellers living in high-risk areas moved to comparatively safe areas during high monsoon season and take rental accommodation for the short-term. Following the monsoon season, the participants return to the high-risk areas.

Table 5. Causes of migration.

\begin{tabular}{ccc}
\hline Causes of Migration & Frequency & Percentage \\
\hline Not migrated (Native) & 98 & 47.1 \\
\hline Landless in the previous place & 58 & 27.9 \\
\hline For job & 26 & 12.5 \\
\hline For education & 12 & 5.8 \\
\hline For business & 8 & 3.8 \\
\hline Rohingya crisis & 6 & 2.9 \\
\hline Total & 208 & 100.0 \\
\hline
\end{tabular}

Source: Field survey, August 2018.

\subsection{The Reasons for Living in High-Risk Areas}

Although residents live in the high-risk areas, they justify the locations due to land ownership and availability of means of livelihood in the hilly areas. One resident at Matiranga, Rangamati stated: "I was much fortunate to buy land at a low rate that allowed me to have own land". The reasons for living in the high-risk areas include: the low price of land; no other alternative land to live; work purposes; and considered a risk-free area (Table 6). Before the 2017 landslide events, the area was considered a comparatively safe place for the people who used to live in the riverbank erosion areas and the tropical cyclone-prone areas. Some residents came to Rangamati City from the remote hilly areas to organise better education for their children. Discussions with one key administrative official in Cox's Bazar suggested that the GoB owns most of the land and the locals who live adjacent to the hills are landless. Those who failed to obtain a safe place on plain land have accepted to live in highly vulnerable 
areas along the hill slopes. Administrative staff and key informant interviews in Chittagong suggest that the people who live in the high-risk areas were mainly refugees experiencing disaster-induced displacement from the previous place of residence. The residents at Rangamati district opined that, before the 2017 landslides, they had never experienced disaster in the area. As such, they considered the areas comparatively safe to live. On occasions, the local community do not admit landslide occurrence and paid little attention to the risk associated with landslide disasters. They thought that admission would mean forced evacuation by the GoB. Some female respondents in Chittagong who participated in the survey wanted to be completely anonymous and requested not to publish survey results to administrative officials.

Table 6. The reasons for living in risk areas.

\begin{tabular}{ccc}
\hline Reasons for Living in Risk Areas & Frequency & Percentage \\
\hline Ownership of land & 106 & 51.0 \\
\hline Low price of land & 40 & 19.2 \\
\hline Has no other alternative land to live & 34 & 16.4 \\
\hline Inherited properties & 2 & 1.0 \\
\hline Risk-free area & 12 & 5.8 \\
\hline For business purpose & 2 & 1.0 \\
\hline For work purpose & 12 & 5.8 \\
\hline Total & 208 & 100.0 \\
\hline Source: Field survey, August 2018.
\end{tabular}

\subsection{Disaster Preparation and Response}

Before the 2017 landslides, the residents in Rangamati have not experienced previous disaster. The landslides were an unprecedented disaster. The occurrence of a major disaster on communities increases disaster preparation [41,42]. Following the landslide disasters in 2007 and 2017, the GoB has significantly increased landslide preparation activities. Local communities have helped each other through warning dissemination, which should continue as ongoing activities for an effective warning respond. Currently, about $94 \%$ of the residents have received landslide warnings that are being disseminated by the local governmental organisations. When heavy rainfall lasts for a couple of hours, the Deputy Commissioner (DC) organises the warning about possible landslide occurrence to be disseminated through a hand microphone (Table 7). If heavy rainfall lasts for several hours, the administrative staff under the DC sometimes visits the high-risk areas to execute the evacuation of vulnerable people. There are limited road transport systems for the people who live in the high-risk areas to move to a safe place. It is challenging to reach to communities and to undertake evacuation during heavy rainfall before any landslide occurs. Discussions with administrative officials suggest that there is limited logistical support to organise warning dissemination and evacuation in remote locations. It is challenging that many residents perceive there is a low-risk and consider a disaster might not occur. Even though the government officials organise forced evacuation for residents, the locals manage to return to the house in a short time. Shamol (44), a resident who experienced damage to his building in 2017 at Rangapani of Rangamati, still considers the area safe for him.

Of the respondents, $77 \%$ believe that there are safe public infrastructures where they can take shelter if required. However, during the previous disaster when they faced evacuation, $37.5 \%$ moved to relatives and neighbours' houses. The communities' usage of public buildings such as municipal halls, public school buildings and cyclone shelters as shelter places were $28.9 \%, 10.6 \%$ and $1 \%$ respectively. It was noted that $22 \%$ of the people remained at their houses despite being made aware of the dangers of landslide occurrence. By experiencing issues in shelter centres during past disasters, $68.3 \%$ of respondents suggest they would not move to a shelter centre even if there were substantial 
landslide occurrence in the future. Some residents stated they were kept in the shelter centre as fish shelved one after another. There are differences in views among residents coming from various places. The native Bengali residents usually do not want to go to the shelter centre because of maintaining their prestige/self-esteem; they further opined that people who migrated from other districts went to shelter centre. Comparatively, wealthy people having their buildings had experienced shame going to a shelter centre. The tribal community suggests they would not go to a shelter centre because they were not anxious about landslides. Findings from FGDs suggest parents with young daughters do not want to move to a shelter centre where they might not have a private room and could experience sexual harassment. They also opined that, even if they went, they could experience theft at their houses.

Table 7. Media of warning dissemination.

\begin{tabular}{ccc}
\hline Media of Warning Dissemination & Frequency & Percentage (\%) \\
\hline Microphone & 176 & 77.19 \\
\hline Word of mouth & 28 & 12.28 \\
\hline Television & 18 & 7.9 \\
\hline Internet & 4 & 1.75 \\
\hline Newspapers & 2 & 0.88 \\
\hline Total & 228 & 100 \\
\hline Multiple Answer Consideration \\
\hline Source: Field survey, August 2018.
\end{tabular}

Of the 208 participating respondents, about $12.5 \%$ of respondents received training on landslide risk reduction. However, the remaining $87.5 \%$ did not receive any training on landslide risk reduction. Those who attended the training learned about warning signals, identification of hazards and first aid procedures. The participants received training on landslide risk reduction from the district and sub-district administration. The city corporation, central government, NGOs and volunteer organisations provided training to the vulnerable communities. Of those who participated in the trainings, $62 \%$ opined the trainings were beneficial but the remaining $38 \%$ concluded that the training outcome was not practical due to the lack of reality.

\subsection{Challenges of Relocation to Safe Areas}

The people who live in the high-risk areas do not want to relocate to new safe areas. Many residents opined that a landslide is not a scatter event; they are living in this area due to livelihood opportunities. The majority of the respondents do not consider the area is at risk of a landslide. The tribal community suggests that they would not relocate to plain land. However, they suggest they might consider relocation if this can be organised for the entire tribal community. If the GoB plans to relocate a cluster of tiny houses without livelihood opportunity, they would not accept the relocation package. Every respondent preferred a single house with livelihood opportunity. When severe adversity was faced during the 2017 landslides, some 2124 people moved into 19 shelter centres in Rangamati [43].

Findings from FGD in Cox's Bazar: "some residents opined that they grew their generation there. It is their heredity, culture, sense of place and living within and adjacent to the places. They have not undergone that hardship to leave the area to seek only for a safe place. They have spent their whole life saving to buy land and construct the houses; now someone (indicating to Governmental officials) says to leave the houses. This poised a question; why do we listen to them? If we own our land, why do we move to another area? This is not a feasible way to solve the problem. No area in Bangladesh is completely safe."

People who do not have permanent income opportunities and are landless would move to a suitable place. FGD with residents in Rangamati: "We do not want to relocate to a tribal majority 
area because we are not safe among them. On extreme occasions, those people who have recently migrated to Rangamati and reside in rental houses could agree to relocate to other areas. If we need to die, we die at this place. We would not move to the new area."

Of the 208 respondents, $54 \%$ completely disagreed with relocating to new areas. About $40 \%$ of respondents want to be relocated to a suitable place. The remaining $6 \%$ indicated a few specific suitable places that include inside Chittagong and Rangamati cities and better places adjacent to their current houses (Table 8). Some poor and landless residents would relocate if construction materials, cash, employment and space for constructing a house in plain land were provided. Concerning reasons for non-relocation, the answers included a lack of suitable facilities in a new location; not having a safe place in adjacent areas; possible fragmentations in family relations; do not consider current living areas as at-risk places; and affection for the current location. It is a prerequisite that economic, social and psychological aspects of the community would need to be carefully evaluated to identify an appropriate place for relocation.

Table 8. Participants' responses to relocation.

\begin{tabular}{ccc}
\hline Options of Relocation & Frequency & Percentage (\%) \\
\hline Disagreed with any relocation & 112 & 53.85 \\
\hline Relocation to a suitable place & 83 & 39.90 \\
\hline Relocation to only specific places & 13 & 6.25 \\
\hline Total & 208 & 100 \\
\hline
\end{tabular}

\section{Conclusions and Implications}

Landslides are a common natural phenomenon in many hilly areas around the world. The occurrence of these events is on the rise in Bangladesh due to the increase in arbitrary anthropogenic activities. The findings suggest that excessive rainfall in a short-period or continuous rainfall for long-term periods causes landslides in the fragile hilly areas of Bangladesh. These hilly areas become fragile due to unplanned road transport, unplanned settlement development, arbitrary hill cutting, deforestation, changes in natural drainage, the impact of hydroelectricity plant and population rise associated anthropogenic activities. The poor people who failed to secure a minimum safe place to settle on plain land managed to construct houses in the high landslide risk areas. They mainly live in the high-risk areas because of the opportunities to purchase cheap land, they were landlessness in their previous place and there is income opportunity adjacent to high-risk areas.

Following the major disaster events in 2007 and 2017, the GoB has significantly increased landslide preparation activities. Currently, over $90 \%$ of residents who live in high-risk areas receive warning disseminated by the local government. Preparedness for disasters heavily depends on how communities perceive hazards and their past experiences of disasters. Even though many residents had observed the damages that occurred during previous landslides in areas adjacent to theirs, they consider that their area is safe for living. It was noted that disaster preparation depends on the duration of living, ownership of houses, ethnicity, gender and economic status of the residents. Disaster preparedness can be significantly improved by the careful dissemination of warning signals to local communities through had microphone, mobile SMS and social media (i.e., Facebook, Twitter, etc.). To execute evacuation of local communities at a high-risk period, it will require constructing an acceptable shelter centres in consultation with the communities to determine the provision of facilities available for them. It will require relocating people from high risk areas to avoid future deaths, injuries and property losses associated with landslide disasters. The place of relocation should be selected with full consideration of the local community's opinion and ensure the locations have acceptable livelihood options.

Funding: This research was funded by the Research and Publication Office (Grant number: RPOCU/2018) of the University Chittagong, Bangladesh. 
Acknowledgments: Thanks to the research assistants from the Disaster Action and Development Organisation (DADO) for data collection in southeast Bangladesh. The contents of the research have been much improved by considering positive feedback from two anonymous reviewers, research project collaborator Dr Basanta Raj Adhikari, and Monica Farrow who improved expression and conducted language check.

Conflicts of Interest: The author declares no conflict of interest.

\section{References}

1. Morgan, J.P.; McIntire, W.G. Quarternary geology of the Bengal Basin, East Pakistan and India. Bull. Seismol. Soc. Am. 1959, 70, 319-342. [CrossRef]

2. Ahammad, R. Understanding Institutional Changes for Reducing Vulnerability to Landslides in Chittagong City. Bangladesh. Master's Thesis, Stockholm Resilience Centre, Stockholm University, Stockholm, Sweden, 2009; p. 61.

3. Chisty, K.U. Landslide in Chittagong City: A perspective on hill cutting. J. Bangladesh Inst. Plan. 2014, 7, $1-17$.

4. Sarwar, G.M. Landslide Tragedy of Bangladesh. In Proceedings of the First World Landslide Forum, United Nations University (UNU), Tokyo, Japan, 18-21 November 2008; p. 5.

5. Alam, E.; Chowdhury, M.A.T.; Akbar, M.T. Aspects of socio-environmental problems resulting from hill cutting in Chittagong City of Bangladesh: Local people's perspectives. Pak. J. Soc. Sci. 2005, 3, 1048-1052.

6. Bal, P. Much Preparatory Activities before Rainfall Season but Silent at Other Times. The Daily Prothom-Alo, 11 May 2017; p. 4.

7. Bal, P.; Chakma, S.B. Look Like War Damage Settlement. The Daily Prothom-Alo, 17 June 2017; p. 1.

8. MoDMR. Investigation on the Reasons of the 2017 Landslide and Strategies for Risk Management; A Report Prepared by the Ministry of Disaster Management and Relief (MoDMR); Government of the People's Republic of Bangladesh: Dhaka, Bangladesh, 2017; p. 78.

9. Ahmed, B.; Rahman, M.S.; Rahman, S.; Huq, F.F.; Ara, S. Landslide Inventory Report of Chittagong Metropolitan Area, Bangladesh. Available online: https://discovery.ucl.ac.uk/id/eprint/1467165/ (accessed on 5 June 2020).

10. Hassan, M.M.; Ahmed, S.; Patwary, N.H.; Yeasmin, L.; Shahidullah, S.M.; Sattar, M.A. Environmental degradation through hill cutting in Chittagong district of Bangladesh. Int. J. Nat. Soc. Sci. 2015, 2, 41-54.

11. Islam, M.S.; Hosain, M.; Islam, M.S.; Ahmed, A.S.D.; Hoque, F.; Karim, S.U.; Islam, M.A. Disaster due to slope failure in the Pahartoli area of the Chittagong city, Bangladesh. Int. J. Sci. Eng. Res. 2015, 6, $246-251$.

12. Mia, M.T.; Sultana, N.; Paul, A. Studies on the causes, impacts and mitigation strategies of landslide in Chittagong City, Bangladesh. J. Environ. Sci. Nat. Resour. 2015, 8, 1-5. [CrossRef]

13. Khan, Y.A.; Chang, C. Landslide hazard mapping of Chittagong city area, Bangladesh. Indian Soc. Eng. Geol. 2008, 35, 303-311.

14. Ahmed, B. Landslide susceptibility mapping using multi-criteria evaluation techniques in Chittagong Metropolitan Area, Bangladesh. Landslides 2015, 12, 1077-1095. [CrossRef]

15. Ahmed, B.; Dewan, B. Application of bivariate and multivariate statistical techniques in landslide susceptibility modeling in Chittagong City Corporation, Bangladesh. Remote Sens. 2017, 9, 304. [CrossRef]

16. Das, S.; Raja, D.R. Susceptibility analysis of landslide in Chittagong City Corporation area, Bangladesh. Int. J. Environ. 2015, 4, 157-181. [CrossRef]

17. Mourin, M.M.; Ferdaus, A.A.; Hossain, M.J. Landslide Susceptibility Assessment in Chittagong District of Bangladesh Using Adaptive Neuro Fuzzy Inference System (ANFIS) and GIS. In Proceedings of the International Conference on Disaster Risk Mitigation, Dhaka, Bangladesh, 23-24 September 2017.

18. Islam, M.S.; Hussain, M.A.; Khan, Y.A.; Chowdhury, M.A.I.; Haque, M.B. Slope Stability Problem in the Chittagong City, Bangladesh. J. Geotech. Eng. 2014, 1, 13-25.

19. Khan, Y.A.; Lateh, H.; Baten, M.A. Critical antecedent rainfall conditions for shallow landslides in Chittagong City of Bangladesh. Env. Earth Sci. 2012, 67, 97-106. [CrossRef]

20. Ahasan, M.N.; CHowdhury, M.A.M.; Quadir, D.A. Simulation of a heavy rainfall event 11 June 2007 over Chittagong, Bangladesh using MM5 model. Mausam 2013, 63, 405-416.

21. Rahman, T. Landslide Risk Reduction of Informal Foothill Settlements of Chittagong City through Strategic Design Measure. Master's Thesis, BRAC University, Dhaka, Bangladesh, 2012; p. 128. 
22. Huq, F.F.; Biswas, S.; Hussaini, T.A. Exploring the Social Vulnerability and Risks of Landslide Disasters in BEDBEDI and West Muslim Para Communities of Rangamati City of Bangladesh. In Proceedings of the International Conference on Disaster Risk Mitigation, Dhaka, Bangladesh, 23-24 September 2017.

23. Rahman, M. Landslides: Why and what to do: Findings from roundtable discussion. The Daily Prothom-Alo, 13 July 2017; p. 17.

24. Ferdous, L.; Kafy, A.A.; Roy, S.; Chakma, R. An analysis of causes, impacts and vulnerability assessment for landslide risk in Rangamati district, Bangladesh. In Proceedings of the International Conference on Disaster Risk Mitigation, Dhaka, Bangladesh, 23-24 September 2017.

25. Kafy, A.A.; Rahman, M.S.; Ferdous, L. Exploring the Association of Land Cover Change and Landslides in the Chittagong Hill Tracts (CHT): A Remote Sensing Perspective. In Proceedings of the International Conference on Disaster Risk Mitigation, Dhaka, Bangladesh, 23-24 September 2017.

26. Chakma, M.; Chakma, S. Observation of Recent Catastrophic Landslide at Rangamati Town, Chittagong Hill Tracts. In Proceedings of the International Conference on Disaster Risk Mitigation, Dhaka, Bangladesh, 23-24 September 2017.

27. Islam, M.A.; Islam, M.S.; Islam, T. Landslides in Chittagong Hill Tracts and Possible Measures. In Proceedings of the International Conference on Disaster Risk Mitigation, Dhaka, Bangladesh, 23-24 September 2017.

28. Burton, I.; Kates, R.W.; White, G.F. The Environment as Hazard; The Guilford Press: New York, NY, USA, 1993; p. 290.

29. Hurnen, F.; McClure, J. The effect of increased earthquake knowledge on perceived preventability of earthquake damage. Australas. J. Disaster Trauma Stud. 1997, 3, 1-6.

30. Gaillard, J.C.; Dibben, C.J.L. Volcanic risk perception and beyond. J. Volcanol. Geotherm. Res. 2008, 172, 163-169. [CrossRef]

31. Wegscheider, S.; Post, J.; Zosseder, K.; Mück, M.; Strunz, G.; Riedlinger, T.; Muhari, A.; Anwar, H.Z. Generating tsunami risk knowledge at community level as a base for planning and implementation of risk reduction strategies. Nat. Hazardsd Earth Syst. Sci. 2011, 11, 249-258. [CrossRef]

32. UNISDR. UNISDR Terminology on Disaster Risk Reduction, United Nations International Strategy on Disaster Risk Reduction (UNISDR). 2020, p. 31. Available online: https://www.unisdr.org/files/7817_ UNISDRTerminologyEnglish.pdf (accessed on 15 May 2020).

33. O'Keefe, P.; Westgate, K.; Wisner, B. Taking the naturalness out of natural disasters. Nature 1976, 260 , 566-567. [CrossRef]

34. Hewitt, K. Regions of Risk: A Geographical Introduction to Disasters; Longman: Harlow, UK, 1997; p. 410.

35. Wisner, B.; Blaikie, P.; Cannon, T.; Davis, I. At Risk: Natural Hazards, People's Vulnerability and Disasters; Routledge: London, UK, 2004; p. 471.

36. Alexander, D. Confronting Catastrophe: New Perspectives on Natural Disasters; Terra and Oxford University Press: Harpenden, UK; New York, NY, USA, 2000; p. 288.

37. Glade, T.; Anderson, M.; Crozier, M.J. Landslide Hazard and Risk; John Wiley \& Sons, Inc.: West Sussex, UK, 2005; p. 801.

38. BMD. Last Ten Years Rainfall. Bangladesh Meteorological Department (BMD). Available online: http: //bmd.gov.bd/p/Last-10-years-Rainfall/ (accessed on 18 September 2018).

39. Akhter, S.H. Landslide Added New Problem and Hazard. The Daily Prothom-Alo, 13 July 2017; p. 11.

40. Donner, W.; Rodriguez, H. Population composition, migration and inequality: The influence of demographic changes on disaster risk and vulnerability. Soc. Forces 2008, 82, 1089-1114. [CrossRef]

41. Alam, E. Earthquake and tsunami knowledge, risk perception and preparedness in SE Bangladesh. J. Geogr. Nat. Disasters 2016, 6, 154. [CrossRef]

42. Sattler, D.N.; Kaiser, C.F.; Hittner, J.B. Disaster preparedness: Relationships among prior experience, personal characteristics, and distress. J. Appl. Soc. Psychol. 2000, 30, 1396-1420. [CrossRef]

43. MCHTA. Landslide in Chittagong Hill Tracts: Causes and Mitigation; Ministry of Chittagong Hill Tracts Affairs (MCHTA), Government of the People's Republic of Bangladesh: Dhaka, Bangladesh, 2018; p. 58. 